\title{
AZ EMOCIONÁLIS TARTALMÚ TÁRSADALMI CÉLÚ REKLÁMVIDEÓK HATÁSMECHANIZMUSÁNAK VIZSGÁLATA: FÉLELEM ÉS HUMOR
}

\author{
GERHÁT RÉKA - BALÁZS KATALIN \\ Debreceni Egyetem, Pszichológiai Intézet, Szociál- és Munkapszichológiai Tanszék \\ E-mail: gerhat.reka@arts.unideb.hu
}

Beérkezett: 2018. február 13. - Elfogadva: 2018. május 2.

\begin{abstract}
Jelen tanulmány célja a különbözö emocionális tartalmú, társadalmi célú reklámok (TCR) hatékonyságának empirikus vizsgálata reklámvideók esetén. Társadalmi célú minden olyan marketingtevékenység, mely az egyének egészségét vagy a társadalmi jót célzó tudatosságot, pozitív attitüdöt, viselkedéses szándékot és viselkedést kíuán kialakítani vagy fenntartani. A marketing egyik eszköze a reklám, mely számos csatornán nagy tömegeket ér el a meggyözés érdekében. A komplex kérdöives vizsgálatban 125 fö vett részt. A rekláminger-kategóriák a következöek voltak: erösen félelemkeltô, gyengén félelemkeltố, humoros és semleges reklámfilmek. A vizsgálat tárgy a a kiváltott érzelmek, a releváns attitüdök és a megismerési szükséglet összefüggése a reklámok hatásosságával. A követezô változókban mértük az indirekt hatásosságot: a reklám szubjektiven megítélt figyelemfelkeltô ereje, mennyire elgondolkodtató a vizsgálati személyek szerint, továbbá a megosztási szándék, valamint a reklámfelidézés. Az adatok alapján az intenzív emocionális töltetû (félelemkeltố vagy humoros) videófilmeket gyakrabban osztanák meg a befogadók. Az erốs negatív érzelmeket kiváltó reklámfilmeket elgondolkodtatóbbnak itélték; valamint többször idézték fel ốket, mint a pozitív emocionális tartalmú vagy a semleges reklámokat. Az involváltság és a megismerési szükséglet szintén befolyásolja a reklámok hatásosságát. Összességében az indirekt hatásosságot tekintve úgy tünik, hogy a társadalmi problémákat megragadó reklámfilmekben érdemes erôs félelemkeltést alkalmazni. Azonban a különbözó érdekeket megragadó TCR-ek esetén tartalmat tekintve más hangsúlyok célszerúek.
\end{abstract}

Kulcsszavak: meggyốzés, reklám, társadalmi célú reklám, TCR, emocionális reklám, félelemkeltés, humor, érzelmek 


\section{BEVEZETŐ}

Jelen tanulmány célja a különböző emocionális tartalmú, társadalmi problémákat megragadó reklámvideók hatékonyságának vizsgálata.

Az attitûdök megváltoztatását, a viselkedés befolyásolását célzó kommunikációs módszerek, meggyốzési technikák gyakran tetten érhetôk a személyközi interakciók során (vö. Balázs és Bernáth, 2015). A reklám ellenben a meggyózó üzenetek adott személyek vagy szervezetek által támogatott, tömegkommunikációt célzó formája, mely a befogadók figyelmének felkeltése érdekében a legkülönfélébb eszközöket alkalmazza (pl. Aaker és Myers, 1987; Virányi, 2010). A figyelemfelkeltés különösen fontos a társadalmi célú reklámok (TCR) esetén, amelyek konkrét ígéretek (termékelôny, fogyasztói jutalom/élmény stb.) helyett csupán elvont ajánlatokkal (pl. erkölcsi jutalom, lelkiismereti egyensúly) szolgálhatnak (vö. Sas, 2010).

A társadalmi célú reklámok az egyének egészségét vagy a társadalmi jót célzó pozitív attitûdöt, viselkedéses szándékot, majd viselkedést kívánnak kialakítani vagy fenntartani (Donovan és Henley, 2010), ami a társadalmi problémákkal kapcsolatos alacsony érintettség miatt nehéz feladatnak mutatkozik. Ezen okból kifolyólag a hirdetôk gyakran erôs, emocionális hatáseszközökkel (pl. sokkolás, félelemkeltés, humor) kívánnak hatást elérni. Az azonban ritkán meghatározható, hogy mi hatott ténylegesen, s hogy egy-egy érzelem megjelenítése pontosan milyen reakciót vált ki (pl. Sas, 2010; Smit, van Meurs és Neijens, 2006; Zaltman és MacCaba, 2007).

Sas (2012) szerint a webkorszak felülír számos reklámlélektani szabályt, ugyanis a 2010-es években a legtöbb inger az interneten keresztül éri a személyeket - mindenki válhat meggyőző féllé a közösségi oldalak nyújtotta lehetôségek révén. A megosztás útján vírusként terjedô reklámok (vö. vírusreklámok) kiemelkedôen figyelemfelkeltôek, ezért lehet célszerû mind a kereskedelmi, mind a társadalmi célú reklámok esetében a videóüzenetek online felületeken történô közzététele.

Jelen tanulmány célja a félelemkeltô, valamint a humoros társadalmi célú reklámfilmek hatékonyságának empirikus alapú vizsgálata. A reklámok közvetett hatásosságát a következô módon kívánjuk megragadni: vizsgáljuk a figyelemfelkeltô képességnek, illetve az elgondolkodtatás mértékének szubjektív megítélését, a megosztási szándékot, valamint a felidézési gyakoriságot (vö. Mehta és Purvis, 2006).

\section{A MEGGYÖZŐ KÖZLÉS}

Chaiken, Wood és Eagly (1996) szerint a meggyôzés egy információfeldolgozási folyamat eredményeként bekövetkezô attitüdformáló jelenség, mely megjelenhet egy régi attitûd megerôsítése vagy megváltoztatása, illetve egy új attitûd kialakítása formájában. Ezt kiegészítve Gass és Seiter vélekedésével (Wilson, 2002): a meggyôzési folyamat célja nem más, mint a hiedelmek, az attitúdök, a szándékok vagy a viselkedés befolyásolása. A társadalmi problémákkal kapcsolatos attitűdök és viselkedés vonatkozásában gyakran alkalmazott kutatási keretet a Tervezett viselkedés elmélete (Theory of Planned Behavior, TPB, Ajzen, 1991, lásd 1. ábra) adja, mely szerint az egyén viselkedését közvetlen módon a szándékai határozzák meg, a viselkedéses szándékra pedig az at- 


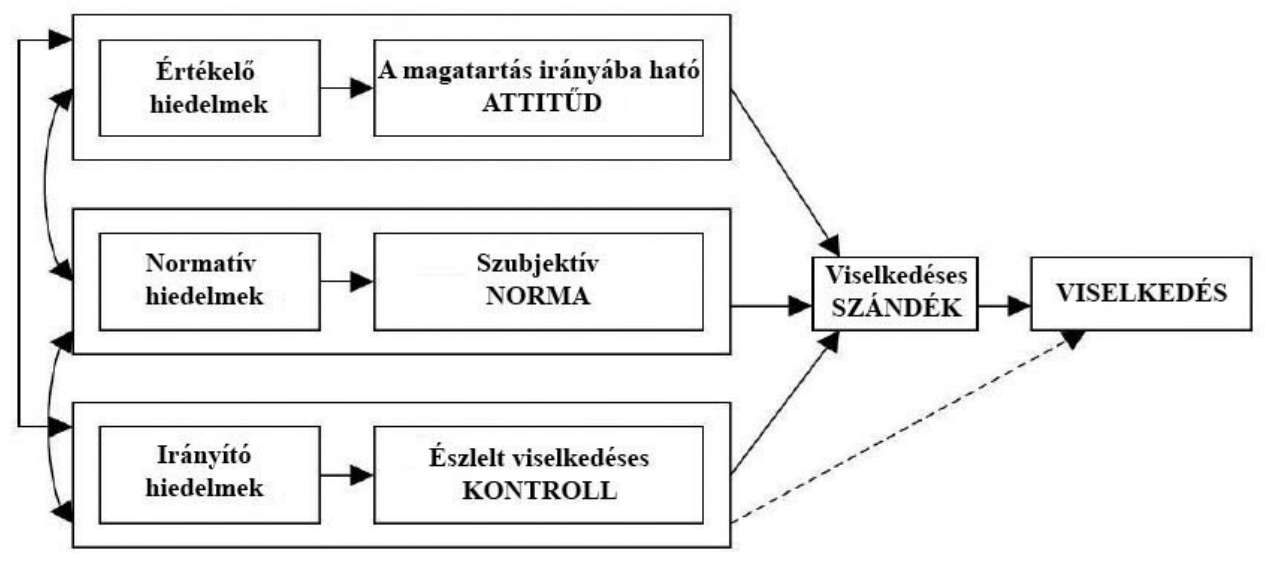

1. ábra. A Tervezett viselkedés modellje (TPB, vö. Ajzen, 1991, 182. alapján)

titûdök, a normák, valamint a viselkedés fölött érzett kontroll fejti ki hatását (utóbbi közvetlen és közvetett módon egyaránt).

Az attitúdök, a normák és az észlelt viselkedéses kontroll mögött minden esetben hiedelmek állnak, melyeket olyan háttértényezók befolyásolhatnak, mint a személyiség, az értékek, az identitás, a tudás, a kultúra, a vallás, a demográfiai jellemzôk, a szocioökonómiai változók, valamint a meggyôzô üzenetek (Ajzen, 1991).

Az attitûdváltozásra vonatkozó két klasszikus kettősfolyamat-modell, a Feldolgozási Valószínúségi Modell (Elaboration Likelihood Model, ELM; Petty és Cacioppo, 1986), valamint a Heurisztikus Szisztematikus Feldolgozási Modell (Heuristic-Systematic Model, HSM; Chaiken, Lieberman és Eagly, 1989). A terminusaik eltérôek, lényegüket tekintve azonban nagyon hasonló információt hordoznak. Az ELM centrális és perifériás feldolgozási utakat különböztet meg, míg a HSM szisztematikus és heurisztikus útnak nevezi a két feldolgozási módot. A centrális vagy szisztematikus út aktív, az érvek alapos megfontolásával és az egyén sémáiba integrálásával járó folyamatokat foglal magába; míg a perifériás és heurisztikus utak erôfeszítés nélküli múveleteket, a releváns információk feldolgozásának teljes hiányát, heurisztikák alkalmazását jelentik (vö. Chaiken és mtsai, 1989; Petty és Cacioppo, 1986).

A feldolgozás módja mindenkor a személy motivációjának, releváns kognitív képességeinek, involváltsági szintjének és aktuális állapotának a függvénye. További, képességekre ható tényezôkként említendôk a különbözó figyelemelterelô jelenségek a meggyôzố üzenetben: az elmélyült gondolkodást igényló témák esetén a kizökkentô ingerek (fény- és hanghatások stb.) csökkenthetik a témareleváns gondolkodás szintjét (Petty és Cacioppo, 1986; Petty, Cacioppo és Schumann, 1983).

A felsorolt tényezók mellett figyelmet érdemelnek bizonyos stabil személyiségjellemzốk is, melyek hajlamosabbá tehetik a személyt a centrális vagy perifériás úton történô feldolgozásra. Előbbire többek között a befogadó megismerési szükséglete (Need for Cognition, NFC; Cacioppo és Petty, 1982), valamint magas kiértékelési szükséglete (Need to Evaluate, NTE; Jarvis és Petty, 1996) hajlamosíthat. Ugyanakkor 
az érzelmek iránti igény (Need for Affect, NFA; Maio és Esses, 2001) magas szintje a perifériás feldolgozást valószínúsíti, ugyanis a modellek szerint az érzelmi alapú, valamint a hangulat irányította döntéshozatal a periférikus úton történô feldolgozás részét képezi (Fiske, 2006).

\section{A REKLÁM MINT A MEGGYÖZÉS ESZKÖZE}

Stewart, Morris és Grover (2007) szerint a reklámok tartalom alapján történó meghatározása két általános dimenzió: egy kognitív vagy információs, illetve egy affektív vagy emocionális dimenzió mentén valósulhat meg. Mindkettô magába foglal továbbá egy verbális (racionális érvek) és egy nonverbális (a verbális üzenet jelentését kiegészítô és tisztázó nyelvi kifejezőeszközök, képek, zenék stb.) komponenst is. A tisztán kognitív és tisztán verbális elemekkel dolgozó reklámokhoz képest az emocionális töltetú, nonverbális komponenseket is tartalmazó üzenetek fokozzák a hallgatóság fogékonyságát, a feldolgozás mértékét, ezáltal az attitûdváltozást, majd pedig a kívánt viselkedés elérésének valószínúségét.

Mehta reklámhatás-modellje (Advertising Response Modeling, ARM; Mehta, 2000) szerint, az attitúdváltozásra vonatkozó kettôsfolyamat-modellekhez hasonlóan, a reklámkommunikáció feldolgozásának is két útja lehetséges. A centrális út esetén a termék vagy márka megjelenése hatására a befogadó felidézi a márkára vonatkozó elôzetes tapasztalatait, a termékkel/márkával kapcsolatos attitúdjeit. A perifériás úton történô feldolgozást pedig a reklám kivitelezése határozza meg, ami a reklám iránti attitûdöt formálva a reklám kedvelését vagy elutasítását válthatja ki. A reklám iránti attitűdök közvetett módon hatnak a márka iránti attitűdökre, ugyanakkor a márka iránti attitûdök is eloohangolhatják a reklám iránti attitûdöket. A két feldolgozási mód direkt és indirekt hatásai együttesen formálják a fogyasztó vásárlási szándékát. Az alapvetốn kereskedelmi célú reklámokra kialakított reklámhatás-modell, melyet az 2. ábra szemléltet, a társadalmi célú reklámok esetén is helytállónak tûnik kisebb módosítással. A módosítás lényege, hogy a célváltozó az üzenet elfogadása, a folyamat azt megelőzó lépése pedig az üzenet iránti attitúd, a termék iránti attitúd helyett.

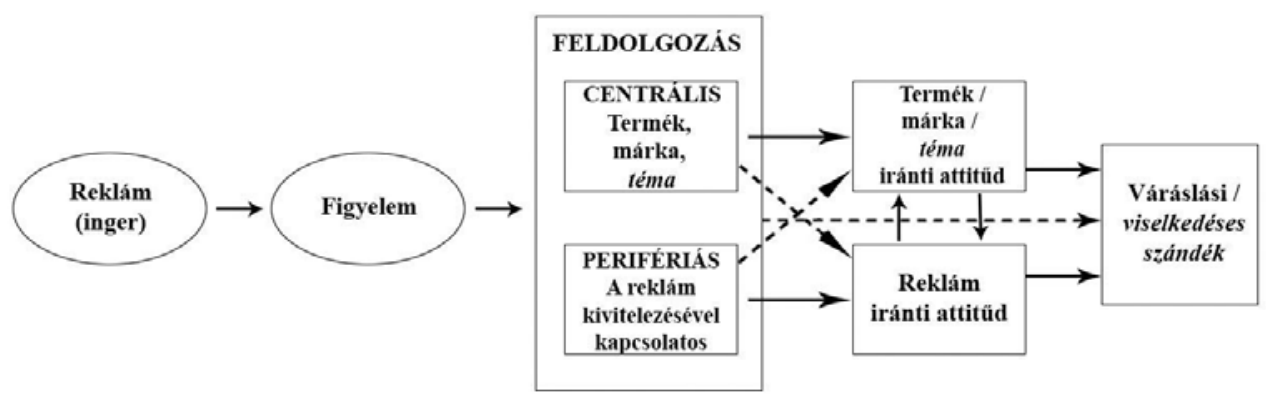

2. ábra. Reklámhatás-modell (vö. Mehta, 2000, 69.) 
A modell a korábbi elméletekhez hasonlóan leírja, hogy a figyelemfelkeltés elengedhetetlen a feldolgozás, s ezáltal a tartós hatás elérése érdekében (Mehta, 2000; Shapiro, 1999). Ebbôl adódóan a reklámokkal foglalkozó szakemberek gyakran tûzik ki vizsgálatuk céljául annak feltárását, hogy milyen ingerek keltik fel a befogadók figyelmét, s milyen típusú üzenetek maradnak fenn nagyobb valószínúséggel a hosszú távú emlékezetben (Montgomery és Unnava, 2007). A reklámfilmek emlékezetességének mérésére használt legelterjedtebb módszer a felidézési gyakoriság vizsgálata, melynek segítségével fontos aspektusai ragadhatók meg a reklámok közvetlen és közvetett hatásosságának egyaránt (vö. Mehta és Purvis, 1994, 2006).

\section{A TÁRSADALMI CÉLÚ REKLÁM}

A társadalmi célú reklámokat a szociális marketing egy elemének tekinthetjük. Donovan és Henley (2010) meghatározása alapján társadalmi célú minden olyan marketingtevékenység, mely az egyének egészségét vagy a társadalmi jót célzó tudatosságot, pozitív attitûdöt, viselkedéses szándékot és viselkedést kíván kialakítani vagy fenntartani.

A Magyar Reklámetikai Kódex (2015, 4. cikkely, 10. bekezdés) kimondja, hogy „a társadalmi célú reklám kivételével a reklám nem kelthet súlyos vagy a fogyasztók széles köre számára indokolatlan, a termék jellegétól idegen félelmet, nem alkalmazhat sokkoló érveket vagy képeket pusztán a figyelem megragadása érdekében". Azaz az etikai szabályzat is megengedôbb a TCR-ekkel szemben. Sas (2010) szerint mindez azzal indokolható, hogy a társadalmi problémák esetén vélhetôen alacsonyra tehetô a befogadók érintettsége. Az érintettség függvényében három típust különít el: (1) saját érdek (pl. dohányzásellenes kampányok, egészséges életmód), (2) más érdeke (pl. adományozás, állatok örökbefogadása, donorprogram) és (3) közös érdek (pl. környezetvédelem, bántalmazásellenes kampányok). A saját, valamint a mások érdekeit szolgáló reklámok esetében elmondható, hogy a befogadók számára a cél sokkal beláthatóbb közelségben helyezkedik el, megragadhatóbb. Mindegyik típusban közös azonban, hogy esetükben csak erôs hatáseszközökkel lehet érdemi hatást elérni: a figyelemfelkeltéshez, ezáltal a reklámkommunikáció feldolgozásához drasztikus, érzelmi meggyôzésen alapuló eszközök szükségesek (Sas, 2010).

\section{Az érzelmek szerepe}

Számos vitatható, egymásnak ellentmondó eredmény születik a különbözó érzelmeket kiváltó videóüzenetek eredményességét illetôen, melynek oka vélhetốen a reklámok összetettségébôl adódik, ami gyakorta alacsony szintú szerkezeti validitáshoz vezet. Mindazonáltal a reklámok gyakrabban építenek az érzelmi hatótényezókre, ezért a különbözó emocionális tartalmú reklámok hatásának vizsgálata a reklámkutatások elengedhetetlen részét képezi (vö. Rucker, Petty és Priester 2007).

Stewart és munkatársai (2007) szerint a reklámok hatásvizsgálata elé további akadályokat állít az ún. érzelmi inkongruencia gyakorisága, mely alapvetôen mindennapi 
jelenség. A reklámok esetén pedig fokozottan jellemzi a befogadókat a több, akár pozitív és negatív érzelem (boldogság és szomorúság, aggodalom és magabiztosság stb.) együttes megélése.

A szakemberek véleményében konszenzus mutatkozik abban, hogy a befogadók jobban emlékeznek az intenzív érzelmi ingerekkel dolgozó reklámokra, mint a kognitív szinten hatókra (pl. Zaltman és MacCaba, 2007). Noha az érzelmi alapú figyelemfelkeltésból származó feldolgozás periférikus úton történik (vö. Fiske, 2006), ezen ingerek - a könnyebb hozzáférhetôségbôl adódóan - nagyobb hatóerejûnek tûnnek a döntéshozatal során (Ambler és Burne, 1999; Montgomery és Unnava, 2007), vélhetôen különösen alacsony involváltság esetén.

Laros és Steenkamp (2005) Érzelmi hierarchiamodelljének felosztása alapján (melyet specifikusan a reklámüzenetek befogadóira, a „fogyasztókra” terveztek) a reklámokban megjelenô pozitív és negatív érzelmek egyaránt 4-4 külön dimenziót alkotnak, melyek aldimenzióiban az érzések kapnak helyet. Az érzelmek hierarchiamodelljét a 3. ábra szemlélteti.

A hierarchiamodell tehát egymástól elkülönítve kezeli az érzelmeket, valamint az érzéseket. Ennek szükségességét számos szakember alátámasztotta, például Nan (2009) szerint a különféle pozitív, illetve negatív érzések akár egymással ellentétes hatást is kiválthatnak a befogadókból. A TCR-ekkel kapcsolatos vizsgálati eredményei rámutattak, hogy az öröm, a remény, a düh, valamint a sajnálat érzete nyitottabbá teszi az egyént a meggyôzô üzenetek mondanivalójára (megközelítés), míg az elégedettség, a szomorúság, a búntudat és a szégyen inkább elkerülést eredményez.

Eisend (2009) metaanalízise alapján levont következtetései szerint a humoros reklámok figyelemfelkeltô hatásúak, valamint pozitív attitûdökhöz vezetnek az egyes termékekre vonatkozóan, azonban a forrás hitelességének megítélésére negatív hatást fejthetnek ki. Ezzel szemben Sas (2007), Schneider (2005) és Virányi (2007) szerint a befogadó a humoros elemekre koncentrál (nem pedig a termékre), s emiatt szívesen megmutatja a reklámfilmet ismerôseinek is - ezáltal az üzenet vélhetôen több személyhez jut el, többeket motiválhat cselekvésre. Alapjában véve azonban a humor veszélyeztetheti a reklámüzenet megértését. Ezen okokból kifolyólag a komolyabb témájú (pl. társadalmi célú) reklámok ritkábban nyúlnak a humor eszközéhez, s a pozitív ér-
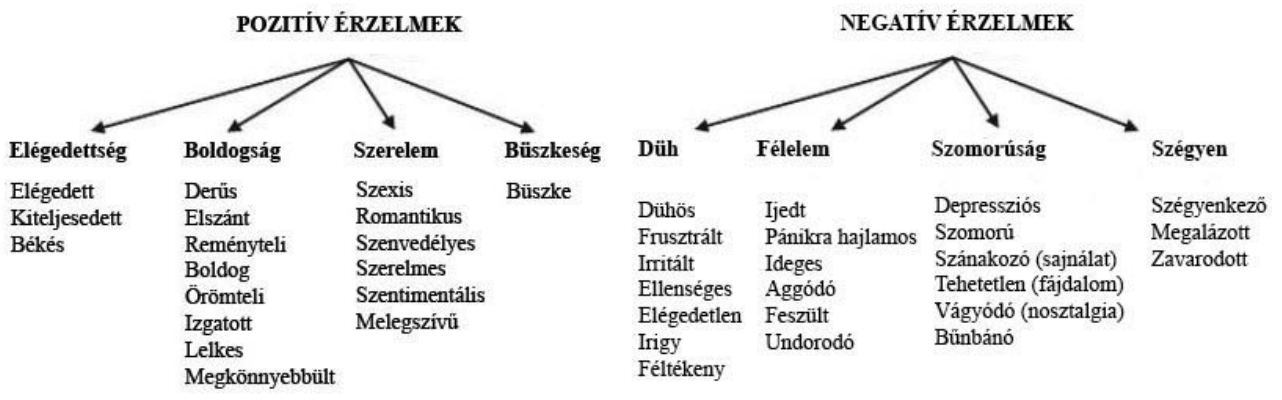

3. ábra. A befogadók érzelmi hierarchiamodellje (vö. Laros \& Steenkamp, 2005, 1441. old alapján) 
zelemdimenziók mentén inkább olyan érzéseket igyekeznek kiváltani a befogadókból, mint a derú vagy a remény. Összességében azonban kevesebb pozitív és több negatív érzelemmel dolgoznak (vö. Stewart és mtsai, 2007).

Az érzelmi dimenziók közül a félelem különbözó megnyilvánulási formái által kiváltott hatások a legvitatottabbak. Hovland, Janis és Kelly (1953), valamint Janis és Feshbach (1953) vizsgálatai képezik a félelemkeltô üzenetek kutatásának alapköveit. Eredményeik szerint leginkább az alacsony vagy a közepes szintû félelemkeltést átélốk ragaszkodnak a késôbbiekben is a véleményükhöz, noha a magas félelemkeltésben részesülôk intenzívebb érzelmeket élnek át, és nagyobb érdeklódést mutatnak a téma iránt. Az okot abban vélték felfedezni, hogy az erôs szintû félelem hosszan tartó aggodalmat eredményez, amely a témától való elfordulást indukál. A szerzók tehát egy fordított U-alakú kapcsolatot írnak le a félelemkeltés és az üzenet elfogadása között.

Weinstein (1980) szerint a félelemkeltés gyakran a sérthetetlenség illúziója miatt vagy a kockázatos cselekvések élvezete okán nem éri el célját. Mindezek mellett a stresszboól adódó koncentrációcsökkenés is gátolhatja a szisztematikus feldolgozás mértékét (Smith és Mackie, 2001).

Witte (1992) definíciója alapján a félelem egy negatív valenciájú érzelem, melyet magas arousalszint kísér, valamint amelyet valóságosnak túnô, személyes relevanciájú környezeti fenyegetés vált ki. Az általa megalkotott Kiterjesztett Párhuzamos Feldolgozási Modell (Extended Parallel Process Model, EPPM; lásd 4. ábra) egy elméletbe integrálja a korábbi modellek alappilléreit. Eszerint a félelemkeltés három fó összetevôbôl áll: tartalmazza a fenyegetést (észlelt súlyosság és kitettség); a félelmet; valamint a fenyegetés elkerülését lehetôvé tevô viselkedés kivitelezési nehézségét (énhatékonyság) és hatékonyságát (válaszhatékonyság).

A modell szerint (Witte, 1992, 1998), amennyiben a fenyegetés nem hatékony, azaz nem vált ki félelmet az egyénből, nem várható el az üzenetnek megfelelô válaszreakció. Abban az esetben, ha az üzenet befogadója mind a fenyegetést, mind az én- és válaszhatékonyságot magasnak észleli, aktiválódik az ún. veszélykontroll folyamata, tehát

Külső stimulus

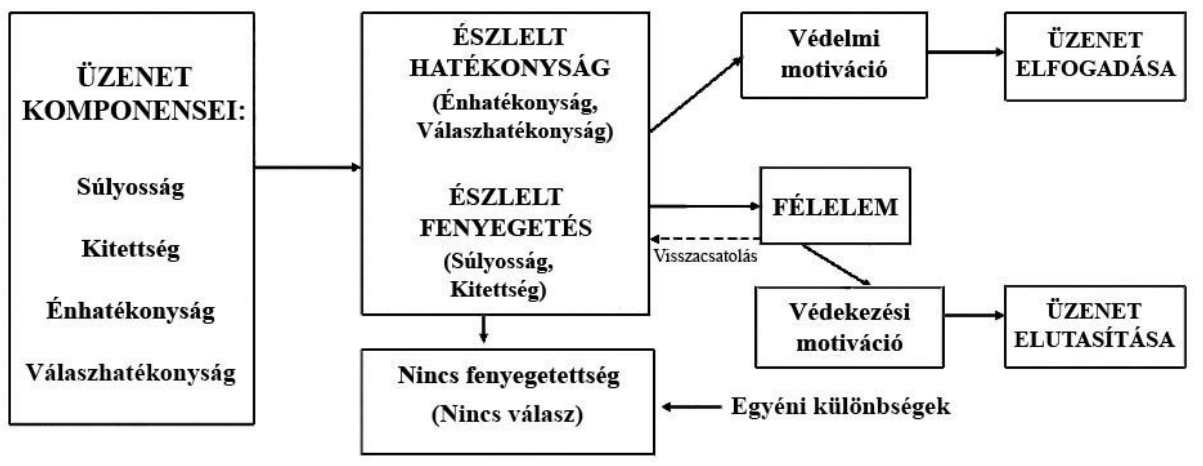

Folyamat

Üzenetfeldolgozás (1. és 2. értékelés)

Kimenetek

हू.

$\frac{\sqrt[3]{3}}{3}$ 
olyan adaptív stratégiákat keres a személy, melyek segítségével hatékonyan megküzdhet az említett fenyegetéssel (védelmi motiváció). Magasnak értékelt fenyegetettség, de alacsony észlelt hatékonyság (a képességekben vagy a tanácsolt megküzdési stratégiában való kételkedés) esetén viszont maladaptív válaszként a félelemkontroll lép életbe, s az egyén eltávolítja magától a fenyegetést, ezzel együtt pedig gyakran magát az üzenetet is (védekezési motiváció). Witte és Allen (2000) metaanalízise alapján azonban a nagyfokú fenyegetettség alacsony énhatékonysággal párosulva gyakran meggyôzhetôbbé teszi a személyeket, míg más esetekben egyáltalán nem mutatkozik interakció a fenyegetés, valamint a hatékonyság között. Az eredmények mögöttes okai azonban feltáratlanok.

Mindezek mellett megválaszolásra várnak olyan kérdések is, hogy vajon mely témák esetén lehet hatásosabb a félelemkeltés; mely célcsoportok fogékonyabbak a negatív érzelmekre - lehetnek-e kulturális vagy korosztálybeli különbségek; s hogy a félelem más érzelmekkel együtt mutatkozhat-e eredményesebbnek az attitúdformálásban, valamint a viselkedéses válasz kiváltásában.

\section{KUTATÁSI CÉL}

A kutatás elsôdleges célja, hogy empirikus alapon felmérje a különbözô emocionális tartalmú, társadalmi problémákat megragadó reklámvideók hatékonyságát fiatal felnôttek körében. Azért erre a célcsoportra esett a választásunk, mert ók viszonylag meggyôzhetôek (Eaton, Visser, Krosnick és Ananad, 2009; Kirmani és Campbell, 2004), így esetükben nagyobb hatékonyság várható.

A közvetett hatásosságot a következó módon kívánjuk megragadni: a reklám figyelemfelkeltô képességének és az elgondolkodtatás mértékének szubjektív megítélését, a megosztási szándékot, valamint a felidézési gyakoriságot vizsgáljuk (vö. Mehta és Purvis, 2006).

A vizsgálatban különbözô intenzitású félelemkeltô és humoros reklámok, valamint kontrollként semleges reklámok hatásosságát vetjük össze.

A szakirodalmi adatok alapján a különbözô valenciájú társadalmi célú reklámok másként hatnak a befogadókra. Bár az emocionális alapú figyelemfelkeltésbôl származó feldolgozás periférikus úton történik, a könnyebb hozzáférhetôségból adódóan, az intenzív érzelmi ingerekkel dolgozó reklámok nagyobb hatóerejûnek tûnnek (vö. Ambler és Burne, 1999; Fiske, 2006; Montgomery és Unnava, 2007; Zaltman és MacCaba, 2007). A befogadók szívesen megmutatják a humoros reklámfilmeket ismerôseiknek, azonban a humor veszélyeztetheti a reklámüzenet megértését (vö. Schneider, 2005; Virányi, 2007). A félelemkeltés tekintetében pedig az mondható el, hogy az erôsen félelemkeltô reklámfilmek rövid távon intenzívebb érzelmeket, ezáltal a téma iránt mutatott nagyobb érdeklôdést váltanak ki, de leginkább az alacsony vagy a közepes szintû félelemkeltést átélôk ragaszkodnak a késôbbiekben is a véleményükhöz (pl. Hovland és mtsai, 1953; Janis és Feshbach 1953). Witte és Allen (2000) metaanalízise alapján viszont úgy túnik, hogy a nagyfokú fenyegetettség teszi meggyôzhetôbbé a személyeket. A szerzők kiemelik, hogy az ellentmondásos eredmények mögöttes okainak 
feltárása további vizsgálatokat igényel. Ebben a kérdésben kíván jelen kutatás állást foglalni.

A szakirodalmi ellentmondások vizsgálatára és az alapfeltevések ellenôrzésére a vizsgálat négy fố hipotézise a következő:

(H1) Az erôs negatív érzelmeket kiváltó reklámfilmek figyelemfelkeltôbbek más ingerkategóriák reklámjainál.

(H2) Az erôs negatív érzelmeket kiváltó reklámfilmek elgondolkodtatóbbak, mint más ingerkategória reklámjai.

(H3) Az erôs negatív érzelmeket kiváltó reklámfilmek emlékezetesebbek, ezeket gyakrabban idézik fel a befogadók.

(H4) Az intenzív pozitív - humoros - és negatív - félelemkeltô - emocionális töltetú videófilmeket gyakrabban osztanák meg egy közösségi portálon, mint a semleges ingerkategória reklámjait.

\section{ELÔVIZSGÁLATOK}

A kutatás etikai engedélyének (száma: 2016/19) kézhezvétele után került sor az elővizsgálatokra; melyek célja a vizsgált társadalmi problémák megválasztása, valamint az ingerkategóriák kialakítása volt. Fontosnak tartottuk, hogy a fővizsgálatban érintett témákat tekintve a célcsoport egy része involvált legyen. Egy-egy vizsgálat során - fóként a résztvevôk fáradása miatt - csak kisszámú társadalmi probléma megragadására nyílik lehetôség, ezért elôvizsgálatban mértük fel a célcsoport érdeklődését a különbözố társadalmi problémákat érintő témák iránt.

Az elsô kérdôív online felületen jutott el 154 fơhöz (98 nô, 56 férfi, életkor: $\mathrm{M}=27,42, \mathrm{SD}=9,57, \mathrm{Med} .=24)$. A résztvevóknek arra kellett választ adniuk, hogy az alább szemléltetett lehetôségek közül mely társadalmi probléma foglalkoztatja óket leginkább. Az elôvizsgálat eredményeit az 5. ábra mutatja.

$\mathrm{Az}$ eredmények összesítése alapján a droghasználat problémájával kapcsolatban magas érdeklôdés mutatkozik, de a magyar lakosságot tekintve a fiatal felnôtt korosztályt leginkább érintô problémáknak a dohányzás, az alkoholizmus, a vezetés és bal-

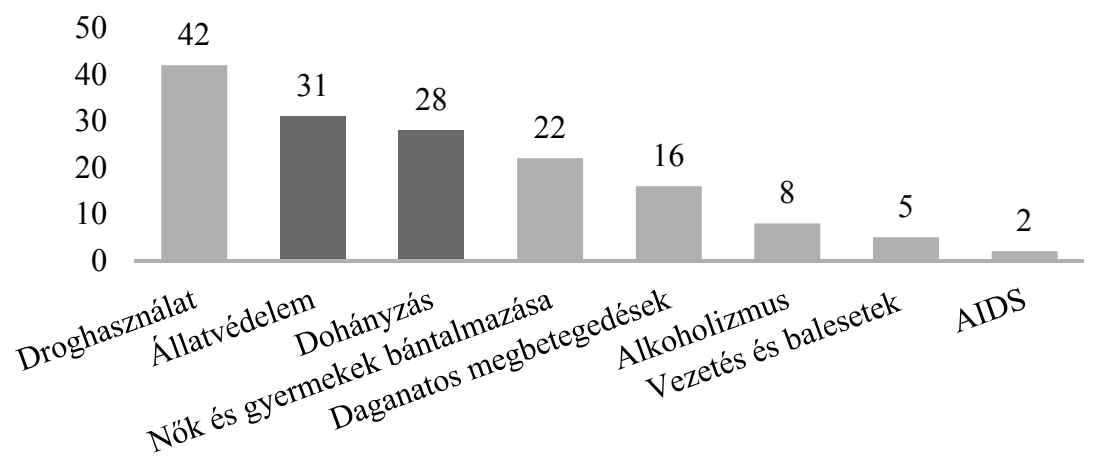

5. ábra. A társadalmi problémák iránti érdeklôdés (/fő) 
esetek, a bántalmazás valamint az állatvédelem tûnnek (vö. Kutatópont, 2012). Hogy biztosan legyenek határozottan involvált személyek, a fôvizsgálat fókuszába a második két legérdekesebbnek tartott téma, az állatvédelem, ezen belül is a háziállatok védelme, valamint a szenvedélybetegségek témaköréból a dohányzás került.

Az elôvizsgálatok második részében a kategóriák kialakítására, a reklámfilmek kiválasztására, majd azok tesztelésére került sor. Az ingerkategóriák létrehozása a Fogyasztók és befogadók érzelmi hierarchiamodelljének (Laros és Steenkamp, 2005) két dimenziója, a félelem és a boldogság dimenziók alapján történt. A négy kategória a következô:

Az erôs félelemkeltô $(E F)$ reklámok várhatóan több és intenzívebb negatív érzést váltanak ki (ijedtség, aggodalom, feszültség, szorongás), mint más kategória reklámjai. A félelem mellett témaspecifikusan és személyiségtôl függóen megjelenhetnek negatív érzések a Düh és a Szomorúság dimenziók mentén is.

A félelemkeltô $(F)$ reklámokban túlnyomórészt a negatív érzések dominálnak (ijedtség, aggodalom, feszültség; illetve témától és személytôl függôen megjelenhet düh és szomorúság). Az EF videófilmeknél kisebb intenzitásúak, s gyakran pozitív érzelem hoz feloldást, megkönnyebbülés vagy remény formájában.

A semleges $(S)$ reklámok általában véve nem hívnak elô erôs negatív vagy pozitív érzelmeket. Bizonyos témák - fóként az állatokat szerepeltetô reklámok - enyhe kellemes érzést, meglepettséget válthatnak ki, de a hosszú távú hatást tekintve semlegesnek mondhatók (vö. Stewart és mtsai, 2007).

A humoros $(H)$ reklámok dominánsan pozitív érzéseket hívnak elô (öröm, lelkesedés, elégedettség, béke). A negatív érzelmeket a lehetôségekhez mérten mellôzik, azonban társadalmi problémák révén, bizonyos mértékben minden téma magában hordozza a negatív emocionális töltetet.

A két téma és a négy ingerkategória mentén, az adforum.com címú weboldalról kutatási célra megvásárolt reklámok közül nyolc angol nyelvú videóüzenet került kiválasztásra. A filmeket 30-60 mp hosszúságúra vágtuk úgy, hogy az üzenet szempontjából releváns részek ne hiányozzanak. A könnyebb érthetôség érdekében a reklámokat magyarul feliratoztuk. A továbbiakban tömören összegezzük ezek tartalmát.

Az állatvédelemmel kapcsolatos erôs félelemkeltô reklámfilm (6. ábra): A reklámban egy kiskutyát állatmenhelyen hagy a gazdája, aki láthatóan kötôdni kezd egy idôsebb kutyához. Pár hét elteltével a kiskutyát örökbe fogadják, de még az indulás elôtt visszatér megkeresni társát, akit már nem talál a helyén. Az utolsó jelenetben az idôs kutya egy menhelyi dolgozóval sétál, aki kezében az elaltatást sejtetố injekciós fecskendốt tartva viszi magával. Az üzenet: „Ne szabjunk határidôt az életüknek!”

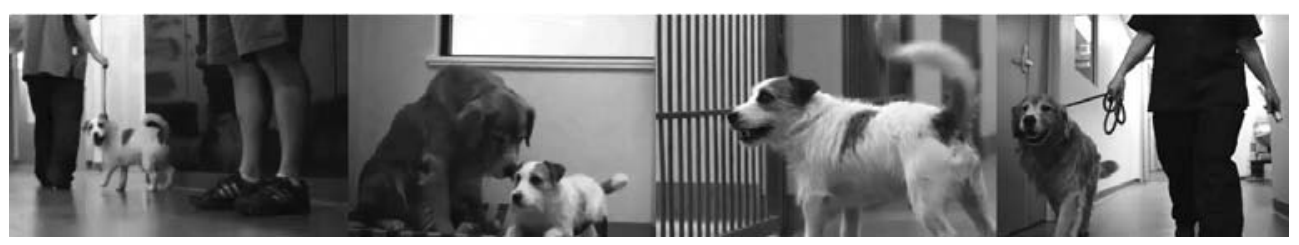

6. ábra. Az állatvédelemmel kapcsolatos erôs félelemkeltô reklámfilm 
Az állatvédelemmel kapcsolatos félelemkeltô reklámfilm (7. ábra): A videóban egy bántalmazott kutya látható, akit megmentenek a haláltól. Megrázó rövidfilm, azonban jelentôsebb részben a kutya felépülését mutatja be, ezért pozitív érzelmeket is elôhív. Az üzenet: „Adományozz vagy fogadj örökbe, hogy megments egy értékes életet!”

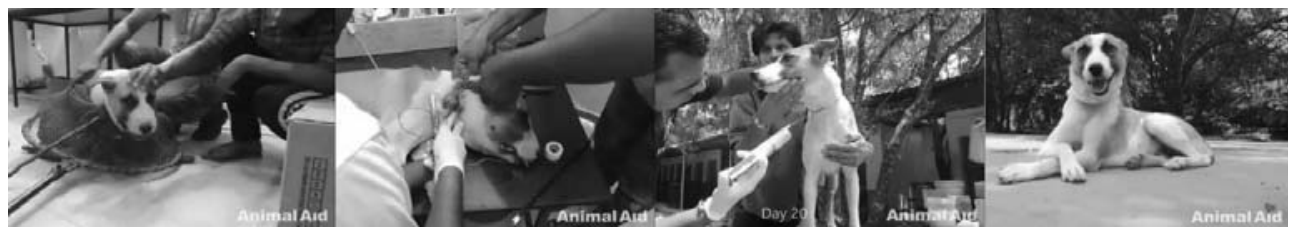

7. ábra. Az állatvédelemmel kapcsolatos félelemkeltố reklámfilm

Az állatvédelemmel kapcsolatos semleges reklámfilm (8. ábra): A reklámban egy kutya sétálgat az üvegfal mögött, várva, hogy gazdára találjon. Az üzenet: „Van egy kisállat a menhelyen, aki találkozni szeretne veled!"

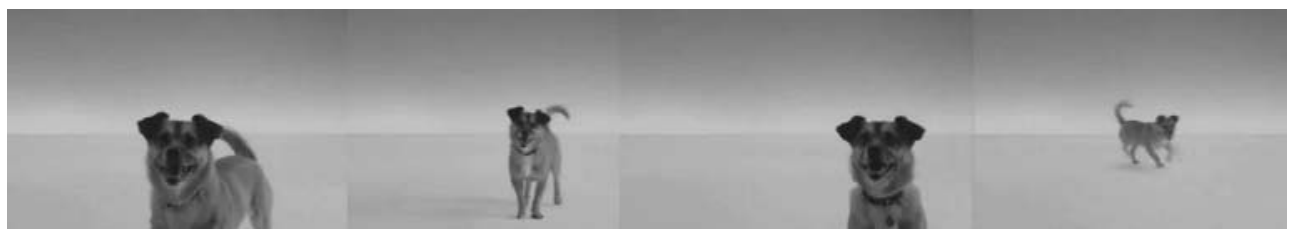

8. ábra. Az állatvédelemmel kapcsolatos semleges reklámfilm

Az állatvédelemmel kapcsolatos humoros reklámfilm (9. ábra): A videóban egy fiatal pár közli a velük szemben üló kutyával, hogy örökbe fogadták. Megnyugtatják, hogy ez nem jelent semmit, csupán a mellette ülố macska és kacsa nem a vér szerinti testvérei. „Légy erôs Mitsy!”- mondják a szárnyaival verdesó kacsának. Az üzenet: „Megválogathatod a családtagjaidat!"

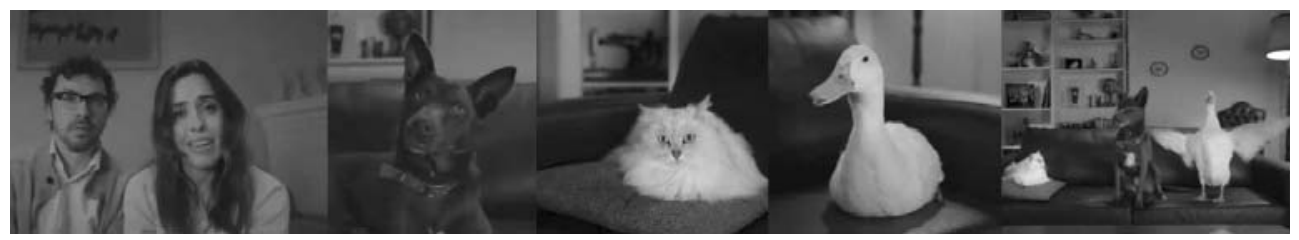

9. ábra. Az állatvédelemmel kapcsolatos humoros reklámfilm

A dohányzással kapcsolatos erôs félelemkeltô reklámfilm (10. ábra): A reklámban egy tüdôtágulattal küzdô férfi szerepel, aki nagyon szenved. Ezt megerôsítik a légzési nehézségekre utaló hangok, valamint a reklámban olvasható feliratok is: „A dohányzás okozta haldoklás ritkán gyors és soha nem fájdalommentes. A tüdôtágulat életed minden percét szenvedéssé teszi." 


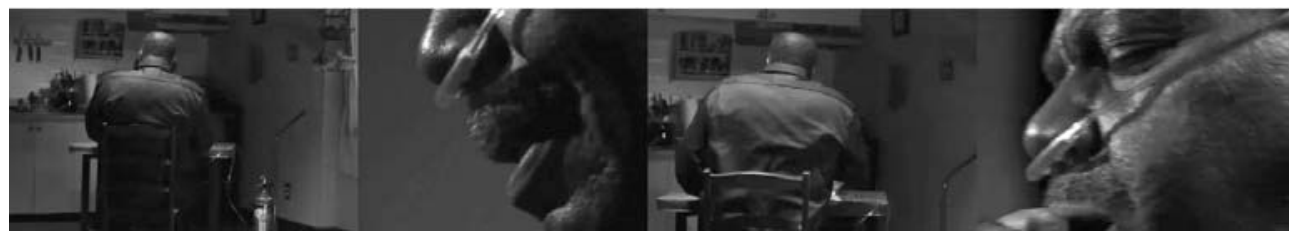

10. ábra. A dohányzással kapcsolatos erôs félelemkeltố reklámfilm

A dohányzással kapcsolatos félelemkeltô reklámfilm (11. ábra): A videóban dohányzó emberek bôre alatt egy féregnek túnô lény kúszik, közeledve a szívük felé. A videó zenei aláfestéssel (Frank Sinatra - I've got you under my skin c. dalából egy részlet), ötletesen hívja fel a figyelmet a dohányzás következményére: a szív- és érrendszerben történô vérrögképzôdésre. Az üzenet: „Minden 35. percben meghal egy dohányzó ember, vérrög következtében."

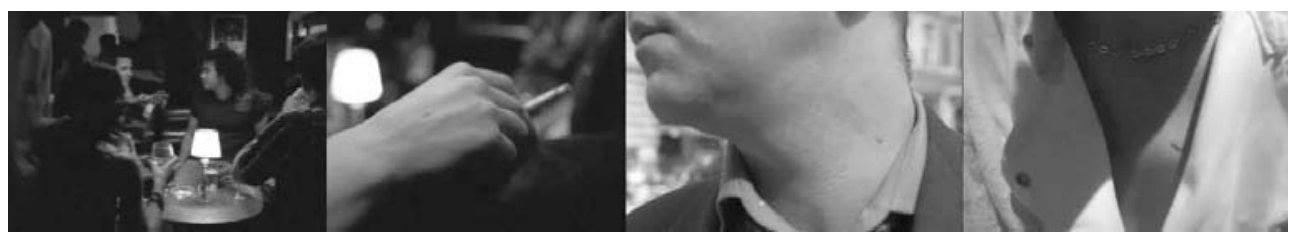

11. ábra. A dohányzással kapcsolatos félelemkeltô reklámfilm

A dohányzással kapcsolatos semleges reklámfilm (12. ábra): A reklám egy fiatal férfit jelenít meg, aki különbözó szituációkat ábrázoló plakátok elé állva szemlélteti, hogy beleillik a képbe. Az utolsó képen egy másik fiatalember cigarettát nyújt a fôszereplônek, ô azonban nemet mond a dohányzásra (nem áll bele a képbe). Az üzenet: „Vajon mindenbe érdemes belemenni?"

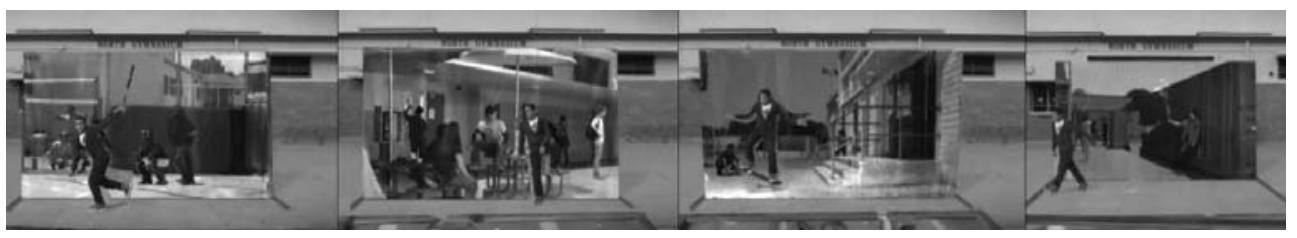

12. ábra. A dohányzással kapcsolatos semleges reklámfilm

A dohányzással kapcsolatos humoros reklámfilm (13. ábra): A videóban a nikotinfüggôséget különböző majmok testesítik meg. Az üzenet: „Minden dohányzó embernek van egy démona (majma)... A leszokás folyamatát személyre szabottan kell megtervezni. Van megoldás!"

A kialakított ingerkategóriák, valamint a választott reklámfilmek tesztelését szintén online kérdôív tette lehetôvé. A vizsgálatban 36 fố vett részt (21 nô, 15 férfi, életkor: 18-56 év között), akik a két reklámnégyesre vonatkozóan hét kérdést válaszoltak meg. A válaszadóknak az egyes reklámfilmek megtekintése után elôször egy ötfokú, emo- 


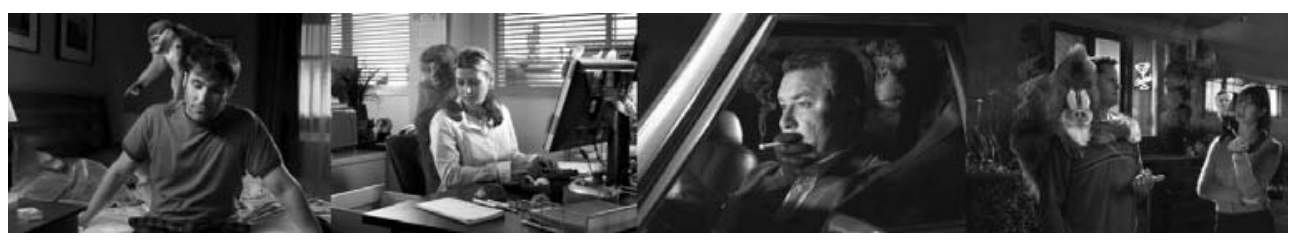

13. ábra. A dohányzással kapcsolatos humoros reklámfilm

tikonokból álló skálán (lásd 14. ábra) kellett megítélniük, hogy milyen érzést vált ki belôlük az adott reklám.
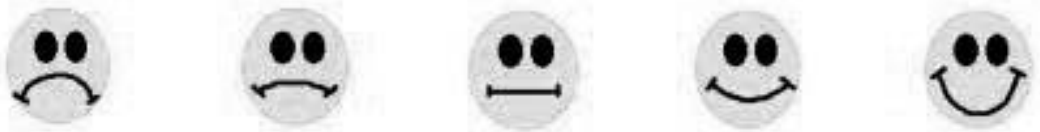

14. ábra. „Milyen érzést vált ki Önbôl a reklám?”

A második pontban egy hétfokú Likert-skálán fejezték ki (1 - egyáltalán nem, 7 - teljes mértékben), hogy véleményük szerint mennyire figyelemfelkeltô, elgondolkodtató, érthetô, valamint mennyire erôs pozitív, illetve negatív érzelmet kiváltó reklámról van szó. Végezetül rövid szöveges válasz formájában írták le, hogy milyen érzelmeket vált ki belôlük az adott film; majd eldönthették, hogy megosztanák-e a videót ismerôseikkel egy közösségi portálon.

Az adatok elemzése az R statisztikai program (R Development Core Team, 2012) segítségével történt. Az elemzések során rendre az érzés, a pozitív érzelem és a negatív érzelem változókat vettük figyelembe a kategóriáknak való megfelelés megítélésekor.

Az adatok nem követtek normális eloszlást (Shapiro-Wilk-próba, Ws $<0,88$, ps < 0,001), ezért nemparaméteres eljárásokat alkalmaztunk. Az azonos témájú, különbözô ingerkategóriákba tartozó reklámfilmek a három mérôszám mentén szignifikáns különbséget mutattak (Friedman-próba, $\chi^{2} \mathrm{~s}<73$, dfs $=3$, ps $<0,001$ ) a megfelelố irányba. A páronkénti Wilcoxon-próba szerint minden reklámpár között szignifikáns az eltérés (Vs < 25,6, ps < 0,01). Az elôvizsgálatok alátámasztották, hogy a választott reklámfilmek az elvárásoknak megfelelố ingerkategóriákba tartoznak, ezért mind a nyolc reklám elemzésre került a fôvizsgálatban. Az elôvizsgálatok eredményeit és tanulságait figyelembe véve mind a dizájn, mind az ingeranyagokat képezô reklámfilmek megfelelönek mutatkoztak.

\section{A FÖVIZSGÁLAT}

A kutatás célja a négy kategóriába tartozó (erôs félelemkeltô - EF, félelemkeltô - F, humoros - H és semleges - S) társadalmi célú reklámfilmek hatásvizsgálata. A fố változók a figyelemfelkeltés, az elgondolkodtatás szubjektíven megélt mértéke, a megosztási szándék, valamint a felidézési gyakoriság. Továbbá mértük a kiváltott érzelmeket Li- 
kert-skálán explicit módon megválaszolható kérdések, valamint nyitott kérdések (rövid szöveges válasz - érzelemmegnevezés) formájában; illetve viselkedéses válaszokat mérô eljárással (videófelvétel-készítés az érzelemmegnyilvánulásokról). A vizsgálat tárgyát képezte, hogy a kiváltott érzelmek mikor és milyen mértékben vannak összefüggésben a hatást mérô elemekkel. Vizsgáltuk továbbá a témareleváns attitúdök hatását is.

\section{Vizsgálati minta és eljárás}

A résztvevôk közül 45 fô iskolaszövetkezet által közvetített, 61 fó pedig személyes megkeresést önként elfogadó személyekből, azaz önkényes mintavételbôl származott. Részben ezzel kívántuk biztosítani a minta heterogenitását. A vizsgálat esetükben papír alapú kérdőíves módszerrel zajlott 12-18 fős csoportokban, és körülbelül 45 percet vett igénybe. A közvetített személyek anyagi jutalomban (1500 Ft); az önkéntes, papír-ceruza tesztet kitöltôk pedig apró ajándékokban (csokoládé, cukorka) részesültek. 30 válaszadó online formában töltötte ki a kérdôívcsomagot, melynek elérési linkjét egy közösségi oldalon keresztül kapták meg. Az instrukciók minden résztvevôt biztosítottak az önkéntességrôl, az anonimitásról, valamint az adatok bizalmas kezeléséról.

A 136 vizsgálati személyból 125 fô $(91,91 \%)$ töltötte ki hiánytalanul a demográfiai kérdéssorral együtt a kérdôíveket, így a továbbiakban 125 fó adatai kerültek elemzésre. A válaszadók átlagéletkora 25,15 év ( $\mathrm{SD}=7,39, \mathrm{Med}$. = 23). A nemek eloszlása egyenlootlennek mondható (79 nô és 46 férfi). A vizsgálatban érettségizettek vettek részt a legnagyobb arányban, ôk tették ki a minta több mint a felét (71 fô). Ennek oka, hogy fôként aktív hallgatói státuszú egyetemistákat sikerült elérni. A fốiskolát vagy egyetemi BA képzést teljesítettek száma a mintában 42 fô, MA diplomával 10 fô, doktori végzettséggel 2 fő rendelkezik.

\section{Módszer}

A fôvizsgálat egy komplex kutatás egy része, amely kutatás hét kérdôívból állt. Annak érdekében, hogy az olvasó számára teljes rálátást biztosítsunk a vizsgálat folyamatára, minden felvett kérdôívet bemutatunk, de jelen tanulmányban ezeknek csak egy részét dolgozzuk fel. A kérdôívcsomag elsố oldalát egy részletes tájékoztató alkotta, amely lehetôséget adott a vizsgálatban való részvételre tett beleegyezésre.

Az elsố kérdôív a dohányzással és állatvédelemmel kapcsolatos attitûdöknek: a társadalmi problémák észlelt súlyosságának, a személyek észlelt énhatékonyságának, valamint érintettségének felmérését tette lehetôvé. A kérdéssor a Kockázatvállaló Viselkedés Diagnózis (Risk Behavior Diagnosis, RDB) Skála (Witte, McKeon, Cameron és Berkowitz, 1995) alapján került kialakításra, amely eredetileg az EPPM (Witte, 1992, 1994) tesztelését szolgálja. A kérdôív hat dohányzásra, illetve hat állatvédelemre vonatkozó itemet tartalmaz, s az egyes dimenziókba mindkét téma mentén 2-2-2 tétel tartozik. Az állításokról hétfokú Likert-skálán kell eldönteniük a résztvevooknek, hogy mennyire értenek velük egyet (végpontok: 1 - egyáltalán nem értek egyet, 7 - teljes mértékben egyetértek). A skála néhány példaiteme: 
Észlelt súlyosság - A dohányzás súlyos negatív következményekkel jár.

Észlelt érintettség - A dohányzás káros hatásai engem is fenyegetnek.

A vizsgálat második részében a Megismerési szükséglet skálát (NFC; Cacioppo és Petty, 1982, fordítás: Daradics, 2013) töltötték ki a résztvevôk. A kérdôív egy olyan személyiségjellemzó mérésére szolgál, mely bejósolhatja a befogadók kognitív feladatokhoz való viszonyát általában. A kérdôív 18 állítást tartalmaz.

A kutatás során a kérdôív szeparáló funkciót is ellátott: arra szolgált, hogy elkülönítse az előzetes, témareleváns attitúdmérést a reklámhatás-vizsgálattól.

A harmadik pontban a reklámfilmek megtekintése és megítélése következett. Annak érdekében, hogy a reklámok hatásai kevésbé interferáljanak (Aaker, Stayman és Hagerty, 1986), a témák, valamint az ingerkategóriák váltakozva követték egymást. A sorrendi hatás kivédése céljából két sorrendet képeztünk. Az „A” feltételbe tartozó személyek (61 fô) esetén a következôképp alakult: állatvédelem-humoros (ÁH), dohányzás-erốs félelemkeltô (DEF), állatvédelem-semleges (ÁS), dohányzás-félelemkeltô (DF), állatvédelem-félelemkeltô (ÁF), dohányzás-semleges (DS), állatvédelem-erôs félelemkeltô (ÁEF), dohányzás-humoros (DH). A „B” feltételben (64 fô) ugyanezek fordított sorrendben szerepeltek. Az érzelmi feloldás érdekében mindkét esetben humoros reklám zárta a sort.

A reklámfilmek a papír alapú tesztet kitöltôk számára egy nagy képernyôn kerültek bemutatásra. Az önbevalláson alapuló méréseket arckifejezés-vizsgálattal egészítettük ki, melyet videófelvételek rögzítése tett lehetôvé. Ennek elemzésére jelen tanulmányban, a terjedelmi korlátok miatt, nem térünk ki. A kísérletvezetô nem mutatott érzelmi reakciókat, a reklámokra vonatkozó kérdôívek kitöltése alatt elfordult a résztvevôktôl, többnyire látszólag az ablakon tekintett ki.

Azok számára, akik online formában töltötték ki a kérdőívet, egy átlátható tesztet állítottunk össze a Google Forms kérdőívszerkesztô program segítségével. A reklámfilmeket mind a papír-ceruza, mind az online kérdôívcsomag esetében az elôvizsgálatban használt kérdéssor mentén értékelték a vizsgálati személyek.

A vizsgálat negyedik és ötödik részében az Érzelmek Iránti Igény Skála (Maio és Esses, 2001, fordítás: Daradics, 2013), illetve a Külsô-belsố kontroll kérdôív (Rotter, 1966) kapott helyet, azonban jelen tanulmányban nem kerülnek részletes kifejtésre, mert jelen vizsgálat fókuszában a különbözô emóciókat megjelenítô reklámok alapvetô hatása áll.

A kérdôív hatodik részében került sor az emlékezetesség vizsgálatára. A résztvevôknek szabadon kellett felidézniük három videót a bemutatott nyolc reklámfilm közül, és tömören leírni azok tartalmát. Az emlékezetesség vizsgálata tehát nem szubjektív megítélés alapján, hanem a felidézés gyakoriságának mérésével történt, amely lehetôvé tette az elhúzódó hatás, illetve a reklámok közötti dominancia megfigyelését. Az elemzések során csak azt kívántuk vizsgálni, hogy a befogadók mely reklámfilmeket idézik fel a leggyakrabban. A kérdôívcsomag hetedik, egyben utolsó részében szerepeltek a demográfiai kérdések, melyek a vizsgálati személyek nemére, életkorára és iskolai végzettségére vonatkoztak. A második blokkot négy-négy involváltságra vonatkozó kérdés alkotta. 


\section{Eredmények}

A fớvizsgálat értékelésének elsố lépéseként az attitûdök mérésére kialakított kérdôív, valamint az NFC skála eloszlás-, illetve megbízhatóságvizsgálatára került sor.

Az általunk fejlesztett attitûdök mérésére szolgáló kérdốív megbízhatósága jónak mondható (Cronbach a:0,77). A skálák nem követtek normális eloszlást (ShapiroWilk-próba, $\mathrm{s}<0,94$; ps $<0,01 \mathrm{~W})$, ezért az egyes változók esetében a mediánokat vizsgáltuk, és nemparaméteres eljárásokat alkalmaztunk az elemzések során.

Az NFC skála (Cronbach a:0,89) szintén nem követett normális eloszlást (Shapiro-Wilk-próba, $\mathrm{W}=0,94, \mathrm{p}<0,001)$, ezért ebben az esetben is nemparaméteres eljárásokat alkalmaztunk. A maximálisan elérhetố 126 pontból a mintában 120 volt a legmagasabb, míg a legalacsonyabb érték 27 lett. A medián 94.

Második lépésként a különbözô reklámkategóriákba (EF, F, S, H) tartozó reklámok elemzésére került sor a kiváltott érzés, a pozitív érzelem, valamint a negatív érzelem változók mentén. Az adatok az érzés, illetve a pozitív és negatív érzelem változók esetén nem követtek normális eloszlást (Shapiro-Wilk-próba, Ws $<0,92$, ps $<0,001$ ), így nemparaméteres eljárásokat alkalmaztunk. Az azonos témájú, különbözó ingerkategóriákba tartozó reklámfilmek, a mediánokat tekintve, a három mérôszám mentén, a fővizsgálatban is szignifikáns különbséget mutattak (Friedman-próba, $\chi^{2} \mathrm{~s}<215,75$, $\mathrm{dfs}=3$, ps $<0,001)$. A páronkénti Wilcoxon-próba azt is alátámasztotta, hogy a releváns reklámpárok között minden változó alapján szignifikáns az eltérés (Vs < 1005, ps $<0,001)$. A DS és DH reklámok között egy esetben nem mutatkozott szignifikáns különbség $(\mathrm{V}=1477, \mathrm{p}=0,29)$ - egyik sem váltott ki negatív érzelmet a résztvevôkboól -, mindazonáltal a semleges és humoros reklámok esetén nem is vártunk erôs negatív érzelmi töltetet, tehát az eredmény az elvárásoknak megfelelônek tekinthetô.

A kategóriák elkülönülésének vizsgálata után a figyelemfelkeltés, illetve az elgondolkodtatás változók elemzésére került sor. Az adatok szintén nem követtek normális eloszlást (Shapiro-Wilk-próba, Ws $<0,76$, ps $<0,001$ ), így ebben az esetben is a mediánokat összegezzük (lásd 1. táblázat).

$\mathrm{Az}$ azonos témájú, különbözô ingerkategóriákba tartozó reklámfilmek között, a mediánokat tekintve, a két mérôszám mentén vannak szignifikáns különbségek (Friedman-próba, $\chi^{2} \mathrm{~s}<139,94, \mathrm{dfs}=3$, ps $<0,001$ ). Az állatvédelemre vonatkozó reklámfilmek közül csak a semleges túnik kevésbé figyelemfelkeltônek, mint a félelem-

1. táblázat. A figyelemfelkeltés és elgondolkodtatás változók értékelésének mediánjai

\begin{tabular}{l|l|c|c}
\hline Ingerkategória & Téma & Figyelemfelkeltés & Elgondolkodtatás \\
\hline \multirow{2}{*}{ Erôs félelemkeltō } & Állatvédelem & 6 & 6 \\
\cline { 2 - 4 } & Dohányzás & 6 & 6 \\
\hline \multirow{2}{*}{ Félelemkeltố } & Állatvédelem & 6 & 5 \\
\cline { 2 - 4 } & Dohányzás & 5 & 5 \\
\hline \multirow{2}{*}{ Semleges } & Állatvédelem & 4 & 4 \\
\cline { 2 - 4 } & Dohányzás & 5 & 4 \\
\hline \multirow{2}{*}{ Humoros } & Állatvédelem & 6 & 4 \\
\cline { 2 - 4 } & Dohányzás & 5 & \\
\hline
\end{tabular}


keltố vagy a humoros reklámok. A dohányzásellenes videófilmek esetén pedig a páronkénti Wilcoxon-próba alapján a figyelemfelkeltés tekintetében elmondható, hogy csak az erôs félelemkeltô ért el magasabb értéket, s tért el szignifikánsan a többitôl (DEF-DF, DEF-DS, DEF-DH rendre: $\mathrm{V}=393,5, \mathrm{p}<0,001 ; \mathrm{V}=503,5, \mathrm{p}<0,001 ; \mathrm{V}=336, \mathrm{p}<0,001)$. Ez alapján az empirikus adatok csak a dohányzásellenes reklámok esetén támasztják alá az elsô hipotézist. A második hipotézist viszont, miszerint az erôsen félelemkeltô reklámok elgondolkodtatóbbak, megerôsítik az empirikus adatok (DEF-DF, DEF-DS, DEF-DH, AEF-AF, AEF-AS, AEF-AH rendre: $\mathrm{V}=540,5, \mathrm{p}<0,001$; $\mathrm{V}=1436, \mathrm{p}<0,001$; $\mathrm{V}=908,5, \mathrm{p}<0,001 ; \mathrm{V}=1116,5, \mathrm{p}<0,01 ; \mathrm{V}=63,5, \mathrm{p}<0,001 ; \mathrm{V}=318, \mathrm{p}<0,001)$.

Összességében elmondható, hogy mind a figyelemfelkeltés, mind az elgondolkodtatás tekintetében aránylag magasra értékelték a reklámfilmeket, azonban a semlegeseknél figyelemfelkeltôbbnek ítélték a félelemkeltô reklámokat. A leginkább elgondolkodtatónak az erôs félelemkeltô videóüzeneteket tartották.

A figyelemfelkeltés, valamint az elgondolkodtatás változókkal kapcsolatos eredmények feltárását az emlékezetesség vizsgálata követte. Az egyes reklámfilmek felidézési gyakoriságának elemzését a 15. ábra szemlélteti.

Az ábra alapján látható, hogy nem azonos az eloszlása a négy reklámkategória fel-

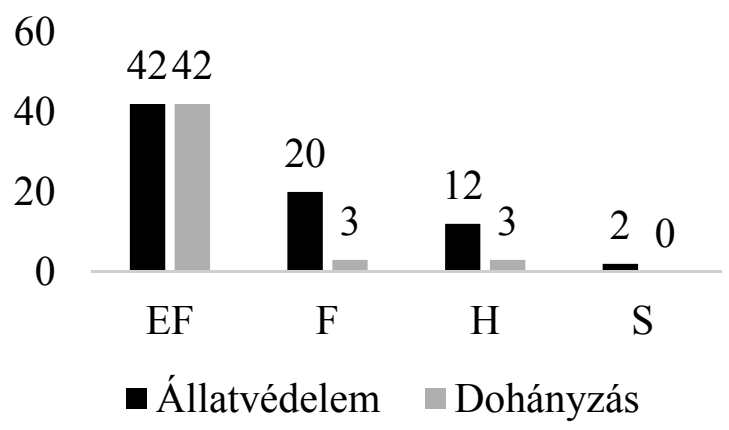

15. ábra. A reklámfilmek felidézési gyakorisága

idézésének $\left(\chi^{2}=140,13, \mathrm{df}=7, \mathrm{p}<0,001 ; \chi^{2}=129,97, \mathrm{df}=7, \mathrm{p}<0,001\right)$. Leggyakrabban erôs félelemkeltố reklámokat idéztek fel, míg összességében egy eltolódás látszik az állatvédelmi témájú videóüzenetek felidézésének irányába. Az adatok egybehangzóak a harmadik hipotézissel, miszerint az erôsen félelemkeltố reklámokat gyakrabban idézik fel a befogadók.

A 125 vizsgálati személy közül 119 fô három reklámot is felidézett, 1-1 fố csak kettô, illetve egy reklámot tartott emlékezetesnek, és csupán egy résztvevô nem adott választ a feltett kérdésre.

Az érzés, valamint a pozitív érzelem változó nem mutatott kapcsolatot a felidézéssel, a negatív érzelem változó azonban igen. A kettô között pozitív, szignifikáns összefüggés látszott (Khí-négyzet próba, $\chi^{2}=94,029$, df $=21, p<0,001$ ), amely közepes erôsségúnek mondható (Kramer-féle $\mathrm{V}$ érték: 0,50). A vizsgálati személyek azt a reklámot idézték fel leggyakrabban elsố helyen, amely a legszélsôségesebb negatív érzelmeket váltotta ki belőlük. 
Az elôzetesen felmért attitûdök, valamint a megismerési szükséglet nem mutattak szignifikáns összefüggést a felidézéssel, azonban a válaszadók érvekkel támasztották alá a választásukat, annak ellenére, hogy nem kaptak arra irányuló instrukciót, hogy indokolják meg a döntésüket. Ezen okból kifolyólag a vizsgálatot tartalomelemzéssel egészítettük ki, mely során a leírások kódolását az elsô szerzô végezte: azt számolta öszsze, hogy hány darab érvet fogalmaztak meg az egyes vizsgálati személyek. A válaszok egyértelmúek voltak, így nem éreztük szükségét másik kódoló bevonásának.

Az eredmények alapján a résztvevôk több érvvel támasztották alá a választásukat abban az esetben, ha magasabb volt az NFC-szintjük, noha nem kaptak arra irányuló instrukciót, hogy indokolják meg döntésüket. A kapcsolat szignifikáns (Spearman-féle rangkorreláció, $\rho=0,348, \mathrm{~S}=211970, \mathrm{p}<0,001)$, de gyenge erósségú.

A felidézési gyakoriságra vonatkozó adatok értékelését a megosztási szándék változó eredményeinek feltárása követte. Az egyes reklámokkal kapcsolatos megosztási szándék gyakoriságát a 16. ábra szemlélteti.

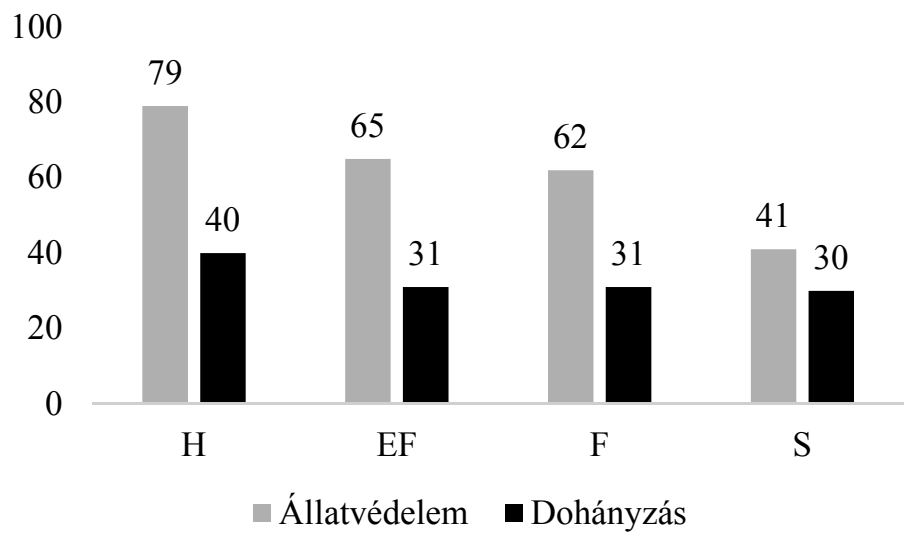

16. ábra. Az egyes videofilmek megosztási szándékának gyakorisága (/fő)

Az ábra alapján elmondható, hogy az állatvédelemmel kapcsolatos reklámokat gyakrabban osztanák meg a vizsgálati személyek. Fontos megjegyezni, hogy egy személy akár mind a nyolc videó kapcsán dönthetett úgy, hogy szívesen megosztaná, ezért a gyakorisági adatok nem függetlenek, így az eloszlás egyenletessége nem vizsgálható. Úgy tûnik, hogy a humoros és erôsen félelemkeltô reklámokat gyakrabban osztanák meg, ez alapján a negyedik hipotézis helytállónak tûnik.

A megosztási szándékkal kapcsolatos elemzések következó pontjában az érzés, a pozitív, valamint a negatív érzelem változókkal való összefüggéseinek vizsgálata következett, melynek eredményeit a 2. táblázat szemlélteti.

A táblázat alapján a félelemkeltő üzeneteket, a dohányzásellenes erôs félelemkeltô reklám kivételével, annál szívesebben osztanák meg, minél erôsebb szintú negatív érzéseket és érzelmeket váltanak ki; míg a humoros és semleges reklámok kapcsán az erôs pozitív érzelmek esetén látható ilyen összefüggés. Az ÁEF reklám esetében akkor 
2. táblázat. Az érzelmi reakciók különbségei azok között, akik megosztanák és akik nem a reklámokat (Mann-Whitney-próba)

\begin{tabular}{|l|l|l|l|}
\hline \multirow{2}{*}{ Reklám } & \multicolumn{1}{|c|}{ Érzés } & \multicolumn{1}{|c|}{ Pozitív érzelem } & Negatív érzelem \\
\cline { 2 - 4 } & \multicolumn{2}{|c|}{ Összevetés Mann-Whitney-próbával } \\
\hline ÁEF & $\mathrm{W}=1442, \mathrm{p}<0,002^{*}$ & $\mathrm{~W}=1572, \mathrm{p}<0,02^{*}$ & $\mathrm{~W}=2622,5, \mathrm{p}<0,001$ \\
\hline ÁF & $\mathrm{W}=1685, \mathrm{p}=0,15$ & $\mathrm{~W}=2091, \mathrm{p}=0,48$ & $\mathrm{~W}=2467,5, \mathrm{p}<0,009$ \\
\hline ÁS & $\mathrm{W}=2793, \mathrm{p}<0,001$ & $\mathrm{~W}=2779,5, \mathrm{p}<0,001$ & $\mathrm{~W}=1693,5, \mathrm{p}=0,87$ \\
\hline ÁH & $\mathrm{W}=2687,5, \mathrm{p}<0,001$ & $\mathrm{~W}=2531, \mathrm{p}<0,001$ & $\mathrm{~W}=1247, \mathrm{p}<0,001^{*}$ \\
\hline DEF & $\mathrm{W}=1291, \mathrm{p}=0,27$ & $\mathrm{~W}=1400, \mathrm{p}=0,6$ & $\mathrm{~W}=1674, \mathrm{p}=0,17$ \\
\hline DF & $\mathrm{W}=1240.5, \mathrm{p}=0,18$ & $\mathrm{~W}=1686,5, \mathrm{p}=0,15$ & $\mathrm{~W}=1898, \mathrm{p}<0,01$ \\
\hline DS & $\mathrm{W}=2087, \mathrm{p}<0,001$ & $\mathrm{~W}=1929,5, \mathrm{p}<0,001$ & $\mathrm{~W}=1302,5, \mathrm{p}=0.46$ \\
\hline DH & $\mathrm{W}=2484,5, \mathrm{p}<0,001$ & $\mathrm{~W}=2413, \mathrm{p}<0,001$ & $\mathrm{~W}=1412, \mathrm{p}=0,12$ \\
\hline
\end{tabular}

* A medián nagyobb vagy kisebb azon személyeknél, akik megosztanák.

osztanák meg inkább a videót, ha negatív érzelmeket vált ki, míg az ÁH videót akkor, ha pozitív érzést és érzelmet vált ki.

A megosztási szándék az állatvédelemrôl szóló félelemkeltô reklámok (ÁEF, ÁF) esetében szignifikáns különbséget mutatott az attitûdök mérésére szolgáló kérdôív észlelt súlyosság, valamint észlelt kontrollálhatóság alskálái mentén (Mann-Whitney-próba, Ws < 2345, ps < 0,047). Minél súlyosabbnak ítélték meg az adott társadalmi problémát a vizsgálati személyek, és minél magasabb szintûnek észlelték a hatékonyságukat, annál szívesebben osztották volna meg a témareleváns félelemkeltô videóüzeneteket.

\section{DISZKUSSZIÓ}

A kutatás fố célja a különbözô emocionális tartalmú (erôs félelemkeltô - EF, félelemkeltô - F és semleges - S) TCR-ek hatásosságának vizsgálata volt két társadalmi probléma mentén (házi állatok védelme, dohányzás).

Az ingerkategóriák, valamint a választott reklámfilmek az eredmények alapján megfeleltek az eredeti célnak: az EF reklámok, más kategóriákba tartózó üzenetekhez képest erôsebb negatív érzelmeket váltottak ki a vizsgálati személyekbôl. Az F reklámok kevésbé intenzíven váltottak ki negatív érzelmeket, sốt ezen reklámok esetén gyakori volt az érzelmi inkongruencia. A H reklámok intenzívebb pozitív valenciájú érzelmeket váltottak ki a többi kategória videófilmjeinél; míg az S kategória reklámjai kis mértékben váltottak ki bármilyen érzelmet.

A reklámfilmek közül a szélsôségesen pozitív és negatív érzelmeket kiváltó, valamint az enyhén félelemkeltô üzeneteket figyelemfelkeltôbbnek ítélték a semlegeseknél, az EF üzenetek azonban nem tértek el szignifikánsan az F reklámoktól. Azaz az elsố hipotézist el kell vetnünk. A leginkább elgondolkodtatónak értékelt reklámok az EF videóüzenetek, ami alátámasztja a második hipotézist. Összességében azonban fontos megjegyezni, hogy mind a figyelemfelkeltés, mind az elgondolkodtatás tekintetében magas értékeket adtak a válaszadók, amit eredményezhetett a témák alapvetóen komoly hangvétele, illetve a társadalmi kívánatosság is. 
A vizsgálati személyek elsố helyen leggyakrabban az erôs félelemkeltô reklámokat idézték fel. Emellett elmondható, hogy a befogadók jellemzóen azokra a videóüzenetekre emlékeztek a legjobban, melyek a legszélsôségesebb negatív érzelmeket váltották ki belőlük. Azaz az adatok alátámasztják a harmadik hipotézist. Az elôzetesen felmért attitûdök nem mutattak szignifikáns összefüggést a felidézéssel.

A vizsgálati személyek leginkább a humoros reklámokat osztanák meg. A megosztási szándék függ a témától is: az állatvédelemmel kapcsolatos reklámokat gyakrabban osztanák meg. Összességében leggyakrabban az állatvédelmi humoros videót mutatnák meg másoknak. Azonban a negatív érzelmeket kiváltó állatvédelmi témájú reklámokat is gyakrabban osztanák meg az összes dohányzásellenes üzenetnél. A megosztási szándék, az eredmények alapján, függ a reklámok emocionális tartalmától is: a félelemkeltô üzeneteket annál szívesebben osztanák meg, minél erôsebb szintú negatív érzéseket és érzelmeket váltanak ki; míg a humoros és semleges reklámok kapcsán az erôs pozitív érzelmek esetén látható összefüggés. A negyedik hipotézist megerôsítik az empirikus eredmények, azzal a kitétellel, hogy a megosztás tekintetében a humoros reklámokat részesítik elônyben.

Az állatvédelmi témájú erôs félelemkeltô, valamint a félelemkeltô reklámokat gyakrabban osztották meg azok a személyek, akik súlyosnak ítélték az adott problémát, illetve azok, akik magas énhatékonyságot észleltek.

Az eredmények részben összhangban állnak a szakirodalmi adatokkal: a különbözô valenciájú, társadalmi célú reklámok másként hatnak a befogadókra, s bár az emocionális alapú figyelemfelkeltésból származó feldolgozás periférikus úton történik, a könnyebb hozzáférhetôségból adódóan, az intenzív érzelmi ingerekkel dolgozó reklámok nagyobb hatóerejünek tűnnek (vö. Ambler és Burne, 1999; Fiske, 2006; Montgomery és Unnava, 2007; Sas, 2010; Zaltman és MacCaba, 2007). A befogadók szívesen megmutatják a humoros reklámfilmeket ismerôseiknek (vö. Schneider, 2005; Virányi, 2007), azonban az erôsen félelemkeltô reklámfilmek rövid távon intenzívebb érzelmeket, ezáltal a téma iránt mutatott nagyobb érdeklôdést váltanak ki (pl. Witte és Allen, 2000). Azzal azonban ellentétes eredményekról számolhatunk be, hogy leginkább az alacsony vagy a közepes szintú félelemkeltés tûnik hatásosabbnak (pl. Hovland és mtsai, 1953; Janis és Feshbach 1953).

A célközönség, valamint az érdekek különbözôsége miatt érdekesnek találtuk megvizsgálni a reklámok hatásosságát befolyásoló, illetve a viselkedéses szándékkal összefüggésben álló személyiségjellemzôket és háttértényezôket. Különbség mutatkozik a saját és mások érdekeit képviselő témák esetén ható háttértényezôk, valamint személyiségjellemzôk között. A mások érdekeit szem elôtt tartó társadalmi témák esetén (állatvédelem) az észlelt énhatékonyság tûnik befolyásoló tényezônek.

Összességében elmondható, hogy a társadalmi problémákat megragadó reklámfilmek készítôinek magyar viszonylatban érdemes erôs félelemkeltô tartalmakat alkalmazniuk, azonban a különbözô érdekeket megragadó TCR-ek esetén fontos a releváns háttértényezók figyelembevétele. Úgy tûnik, hogy a másokat képviselô reklámoknak az észlelt énhatékonyságot kell erôsíteniük - hatékony megküzdési stratégiák felsorolása stb. (vö. Witte, 1992) -, míg az egyén saját érdekeiért fellépô üzeneteknek erôs érveket célszerú tartalmazniuk. 
A késôbbiekben érdemes lenne kiterjeszteni a kutatást az idôben elhúzódó hatások vizsgálatával. Ezáltal lehetôség nyílna a félelemkeltés és az üzenet elfogadása között feltételezett fordított U alakú kapcsolat - a hosszú távú hatás - létének vizsgálatára (vö. Hovland és mtsai, 1953; Janis és Feshbach, 1953); valamint a viselkedéses szándék, illetve akár a viselkedéses reakciók mérésére. Az érintettség kapcsán felmerülô kérdések tisztázása is helyet kapna: példának okáért, hogy mely társadalmi problémák esetén vált ki elhatárolódást az involváltság, és melyek esetén teszi nyitottá a személyeket. Továbbá itt a terjedelmi korlátok miatt ki nem fejtett eredményeink alapján, az érzelemmegnyilvánulásokat mérô videófelvételes eljárás alkalmazása differenciáltabb eredményeket hozhat.

\section{IRODALOM}

Aaker, D. L., \& Myers, J. G. (1987). Advertising management. New Jersey: Prentice-Hall.

Aaker, D. L., Stayman, D. M., \& Hagerty, M. R. (1986). Warmth in advertising: measurement, impact, and sequence effects. Journal of Consumer Research, 12(3), 365-381. Letöltve (2018.06.20): http://www.jstor.org/stable/10.2307/254299

Ajzen, I. (1991). The theory of planned behavior. Organizational Behavior and Human Decision Processes, 50, 179-211. doi: 10.1016/0749-5978(91)90020-T

Ambler, T., \& Burne, T. (1999). The impact of affect on memory of advertising. Journal of Advertising Research, 39(2), 25-34. Letöltve (2018.06.20):

https://www.researchgate.net/profile/Tim_Ambler/publication/288284979_The_impact_ of_affect_on_memory_of_advertising/links/56f3c3d908ae95e8b6cce08c.pdf

Balázs K., \& Bernáth Á. (2015). A viselkedés befolyásolására alkalmas kommunikációsmódszerek. In Kovács J. (szerk.), Szociálpszichológiai tanulmányok a Szociál-és Munkapszichológiai Tanszék fennállásának 25. évfordulójára (pp. 207-229). Debreceni Egyetemi Kiadó.

Cacioppo, J. T., \& Petty, R. E. (1982). The need for cognition. Journal of Personality and Social Psychology, 42, 116-131. doi: 10.1037/0022-3514.42.1.116

Chaiken, S., Liberman, A., \& Eagly, A. H. (1989). Heuristic and systematic informationprocessing within and beyond the persuasion context. In J. S. Uleman, \& J. A Bargh (Eds), Unintended thought: Limits of awareness, intention, and control (pp. 212-252). New York: Guilford.

Chaiken, S., Wood, W., \& Eagly, A. H. (1996). Principles of persuasion. In E. T. Higgins, A. Kruglanski (Eds), Social psychology: Handbook of basic principles. New York: Guilford.

Daradics J. (2013). Az érzelmi intelligencia, az érzelmek iránti igény és a megismerés iránti igény összefüggései. Debreceni Egyetem, Pszichológiai Intézet, Debrecen [Diplomadolgozat].

Donovan, R., \& Henley, N. (2010). Principles and practice of social marketing an international perspective. Cambridge: University Press.

Eaton, A. A., Visser, P. S., Krosnick, J. A., \& Ananad, S. (2009). Social power and attitude strength over the life course. Personality and Social Psychology Bulletin, 35(12), 1646-1660. doi: $10.1177 / 0146167209349114$

Eisend, M. (2009). A meta-analysis of humor in advertising. Journal of the Academy of Marketing Science, 37(2), 191-203. doi: 10.1007/s11747-008-0096-y

Fiske, S. T. (2006). Társas alapmotívumok. Budapest: Osiris Kiadó.

Hovland, C., Janis, I., \& Kelley, H. (1953). Communication and Persuasion. New Haven, CT: Yale University Press.

Janis, I. L., \& Feshbach, S. (1953). Effect of fear-arousing communications. The Journal of Abnormal and Social Psychology, 48(1), 78-92. doi: 10.1037/h0060732 
Jarvis, W. B. G., \& Petty, R. E. (1996). The need to evaluate. Journal of Personality and Social Psychology, 70, 172-194. doi: 10.1037/0022-3514.70.1.172

Kirmani, A., \& Campbell, M. C. (2004). Goal seeker and persuasion sentry: How consumer targets respond to interpersonal marketing persuasion. Journal of Consumer Research, 31(3), $573-582$.

Kutatópont (2012). Magyar ifjúság 2012. Letöltve (2018.06.20): http://kutatopont.hu/files/2012/02/magyar_ifjusag_2012.pdf

Laros, F. J. M., \& Steenkamp, J.-B. E. M. (2005). Emotions in consumer behavior: a hierarchical approach. Journal of Business Research, 58, 1437-1445. doi: 10.1016/j.jbusres.2003.09.013

Magyar Reklámetikai Kódex (2015). Letöltve (2018.06.20): http://mrsz.hu/cmsfiles/08/c1/ Magyar_Reklametikai_Kodex_2015.pdf

Maio, G. R., \& Esses, V. M. (2001). The need for affect: Individual differences in the motivation to approach or avoid emotions. Journal of Personality, 69, 583-615. Letöltve: https://www. ncbi.nlm.nih.gov/pubmed/11497031

Mehta, A. (2000). Advertising attitudes and advertising effectiveness. Journal of Advertising Research 40(3), 67-72. doi: 10.2501/JAR-40-3-67-72

Mehta, A., \& Purvis, S. C. (1994). Evaluating advertising effectiveness through advertising response modeling (ARM). Presentation. Advertising and Consumer Psychology Conference, Minneapolis.

Mehta, A., \& Purvis, S. C. (2006). Reconsidering recall and emotion in advertising. Journal of Advertising Research. 46(1), 49-56. Letöltve (2018.06.20): http://gandrllc.com/reprints/ mehtapurvisreconsideringrecall.pdf

Montgomery, N. V., \& Unnava, H. R. (2007). The role of consumer memory in advertising. In G. J. Tellis, \& T. Ambler (Eds), The SAGE handbook of advertising (pp. 105-119). Thousand Oaks, CA: Sage Publication.

Nan, X. (2009). Emotional responses to televised PSAs and their influence on persuasion: An investigation of the moderating role of faith in intuition. Communication Studies, 60(5), 426442. doi: 10.1080/10510970903260236

Petty, R. E., \& Cacioppo, J. T. (1986). The elaboration likelihood model of persuasion. In L. Berkowitz (Ed.), Advances in experimental social psychology (pp. 123-205). New York: Academic Press.

Petty, R. E., Cacioppo, J. T., \& Schumann, D. (1983). Central and peripheral routes to advertising effectiveness: The moderating role of involvement. Journal of Consumer Research, 10, 135-146. doi: 10.1086/208954

Rucker, D. D., Petty, R. E., \& Priester, J. R. (2007). Understanding advertising effectivenessfrom a psychological perspective: the importance of attitudes and attitude strength. In G. J. Tellis, \& T. Ambler (Eds), The SAGE handbook of advertising (pp. 73-88). Thousand Oaks, CA: Sage Publication.

Sas I. (2007). Az ötletes reklám. Budapest: Kommunikációs Akadémia.

Sas I. (2010). Reklám a jóert. Budapest: Kommunikációs Akadémia Könyvtár.

Sas I. (2012). Reklám és pszichológia a webkorszakban. Upgrade 3.0. Budapest: Kommunikációs Akadémia Könyvtár.

Schneider, I. (2005). Humor in der Werbung: Praxis, Chancen und Risiken. Saarbrücken: Vdm Verlag Dr. Müller.

Shapiro, S. (1999). When an ad's influence is beyond our conscious control: Perceptual and conceptual fluency effects caused by incidental ad exposure. Journal of Consumer Research, 26. 16-36. doi: 10.1086/209548

Smit, E. G., van Meurs, L., \& Neijens, P. C. (2006). Effects of advertising likeability: A 10-year perspective. Journal of Advertising Research, 46, 73-83. doi: 10.2501/S0021849906060089

Smith, E., R., \& Mackie, D. M. (2001). Szociálpszichológia. Budapest: Osiris Kiadó. 
Stewart, D. W., Morris, J., \& Grover, A. (2007). Emotions in advertising. In G. J. Tellis, \& T. Ambler (Eds), The SAGE Handbook of Advertising (pp. 120-134). Thousand Oaks, CA: Sage Publication.

Tellis, G. J. (2004). Does advertising really work: How, why, when? Thousand Oaks, CA: Sage Publication.

Virányi P. (2007). Nem igaz, hogy a reklámtól lettem ilyen! Budapest: Gondolat Kiadó.

Virányi P. (2010). Reklámpszichológia. Budapest: Gondolat Kiadó.

Weinstein, N. D. (1980). Unrealistic optimism about future life events. Journal of Personality and Social Psychology, 39, 806-820. doi: 10.1037/0022-3514.39.5.806

Wilson, S. R. (2002). Seeking and resisting compliance. Thousand Oaks, CA: Sage Publication.

Witte, K. (1992). Putting the fear back into fear appeals: The Extended parallel process model. Communication Monographs, 59, 329-349. doi: 10.1080/03637759209376276

Witte, K. (1994). Fear control and danger control: A test of the extended parallel process model (EPPM). Communication Monographs, 61(2), 113-134. doi: 10.1080/03637759409376328

Witte, K. (1998). Fear as motivator, fear as inhibitor: Using the extended parallel process model to explain fear appeal successes and failures. In P. A. Andersen, \& L. K. Guerrero (Eds), Handbook of communication and emotion: Research, theory, applications, and contexts (pp. 423450). San Diego, CA, US: Academic Press.

Witte, K., \& Allen, M. (2000). A meta-analysis of fear appeals: Implications for effective public health campaigns. Health Education and Behavior, 27(5), 591-615. doi:

$10.1177 / 109019810002700506$

Witte, K., McKeon, J., Cameron, K., \& Berkowitz, Z. (1995). The risk behavior diagnosis scale (A health educator's tool). Department of Communication Michigan State University.

Zaltman, G., \& MacCaba, D. (2007). Metaphor in advertising. In G. J. Tellis, \& T. Ambler (Eds), The SAGE Handbook of Advertising (pp. 135-154). Thousand Oaks, CA: Sage Publication.

\title{
IMPACT ASSESSMENT OF ADVERTISEMENT VIDEOS FOR THE SOCIAL GOOD WITH DIFFERENT EMOTIONAL LOADS: FEAR AND HUMOUR
}

\author{
GERHÁT, RÉKA - BALÁZS, KATALIN
}

\begin{abstract}
The goal of the present study is the empirical investigation of the effectiveness of advertisements for the social good, depending on their emotional contents. Marketing activity with social purpose wants to create or maintain a person's health or good social purpose, positive attitudes, behavioral intent and behavior. In our complex questionnaire study we had 125 participants. The investigated advertising categories were: strongly fearful, fearful, humorous, and neutral. The subject of the study is the correlation of emotions triggered, relevant attitudes, and cognitive needs with the effectiveness of advertisements. The relations between the effectiveness and the following factors were studied: reactive emotions; the relevant attitudes, and the need for cognition. The indirect effectiveness was measured on the following variables: the subjectively assessed attention evoking power, perceived thoughtfulness, sharing intention, and advertisement recall. Based on the empirical data, the examinees would share more often the videos with more intense emotional load. The advertisements with negative emotions were assessed as the most thought-provoking; and were recalled more times than the advertisements with positive emotions or the neutral ones. The involvement, and the need for cognition factors also influenced the effectiveness of advertising. Overall, it seems to be beneficial to apply strongly fearful advertisements for the social good. However, depending on whose interest are represented in the message, different emphasis on message factors seem beneficial.
\end{abstract}

Keywords: persuasion, advertisement, advertisement for the social good, emotional advertisements, fear appeal, humour, emotions 